\title{
UTILIZATION OF SELECTED NON-VERTEBRATE WILDLIFE SPECIES IN NIGER DELTA, NIGERIA
}

\author{
Ijeomah $\mathrm{HM}^{*}$ and Alagoa A \\ Department of Forestry and Wildlife Management, University of Port Harcourt, P.M.B.5323,Port Harcourt, Rivers State, \\ Nigeria
}

Accepted: 2 July 2012

\begin{abstract}
Non vertebrate wildlife resources are the priority means of survival for most rural households in developing countries due to their abundance and free accessibility, but factors militating against their availability and utilisation in the Niger Delta of Nigeria are yet to be known. The study was therefore conducted to investigate both consumptive and non-consumptive utilisation of Crab Callinectes spp; Oyster, Ostrea edulis; Periwinkle, Littorina irrorata; and the Raphia palm weevil Larvae, Rhynchophorus phoenicis and the factors militating against utilisation of the species in the study area. Bassambiri and Ogbolomabiri in Bayelsa State and Isaka and Okrika Communities of Rivers State were selected at random from other communities in Niger Delta with abundance of these selected species. Data for the study were obtained through a set of structured questionnaires, in-depth interview and personal observation. A set of questionnaires were administered systematically to $4 \%$ of household representatives in the four selected communities. In all, a total of 301 households were sampled in the four communities. Data obtained were analysed using descriptive statistics such as frequencies and percentages; while Chi-square was used to test significance of associations. Utilisation of Crab, Periwinkle, Oyster and Raphia palm beetle (Edible maggot) is not significantly associated with age, occupation, level of education, and gender but household size $\left(\mathrm{X}^{2}=\right.$ $\left.158.457^{\mathrm{a}}\right)$ and knowledge of the species $\left(\mathrm{X}^{2}=166.699^{\mathrm{a}}\right)$. The species are used for various consumptive and non consumptive purposes in the communities. Most respondents utilise Crab (71.9\%), Oyster (72.2\%) and Periwinkle $\mathbf{7 8 . 5 \% )}$ as food while some respondents sell them for income generation. Crab is sold at 4 individuals for N200.00K (1.29 USD) only. Among the four species studied the Edible maggot is the least used as food (28.7\%) and the least known by respondents $(63.0 \%)$.The flesh of these species are used in preparing cultural delicacies such as Crab soup and Periwinkle soup in Nembe community. In Nembe, Shells of Periwinkle and Oyster are used by respondents in checking erosion, elevating frontages, solidifying marshy grounds, as substitutes for gravel during construction and as source of calcium in feed meals. The factors militating against utilisation of these non vertebrate wildlife species were identified as skin irritation after consumption, cultural belief, religious belief and limited knowledge of respondents about the species. Households in Okrika and Isaka do not utilise the edible maggot, as they lack knowledge of the species. These non-vertebrate species are of utmost importance to the rural people of the Niger Delta. Their decline and depletion could result in loss of income.
\end{abstract}

Key words: Livelihood, Oyster, Periwinkle, Crab, Palm weevil larvae, Niger Delta

\section{INTRODUCTION}

Due to increase in world population, there is tremendous demand for food including protein and minerals (Popoola et al. 2010). To meet this great demand, recently the world ${ }^{\text {ee }} \mathrm{s}$ fish and meat production has increased (WHO 1985; FAO 1997). This was part of attempts to increase the global animal and mineral intake especially in rural areas. But consumption of meat from fish and domestic animals are rarely affordable among rural inhabitants who have traditionally relied on bush meat for animal protein. Even among the wild animals utilized as bush meat, emphasis is only laid on the vertebrate species (Ogogo 2008). Apart from snails, other non-vertebrate species are being neglected whereas they are more frequently utilised by rural households due to their more relative availability, affordability and lesser market value. Among the studies on wildlife species in the Niger Delta none has focused on utilisation of Crab, Periwinkle, Oyster, Palm weevil larvae (Edible maggot) and insects

*Corresponding author: henryijeomah@ yahoo.com 
IJEOMAH: UTILIZATION OF NON-VERTEBRATE WILDLIFE IN NIGERIA

which are common non-vertebrate wildlife species that are more frequently utilised by many households in the region. The study focused to determine the various ways these species are utilized by respondents in the study area.

\section{METHODOLOGY}

The Niger Delta region is located between longitude $5^{\circ} 21^{\prime} 00^{\prime \prime} \mathrm{N}$ and latitude $5^{\circ} 30^{\prime} 30^{\prime \prime} \mathrm{E} /$ 5.35; 5.50833 (Wikipedia 2010). It comprises nine states which are Abia, Akwa Ibom, Bayelsa, Cross Rivers, Delta, Edo, Imo, Ondo and Rivers. These nine states, which produce crude oil, are found in the swamp/fresh water forest ecological zone. Bayelsa and Rivers states were selected based on the abundance and utilisation of these selected non-vertebrate forest species Crab; Callinectes species, Edible maggot: Raphia Palm weevil larva (Rhynchophorus phoenicis), Oyster (Ostrea edulis) and the marsh Periwinkle (Littorina irrorata) by the households therein. Isaka and
Okrika: Bassambiri and Ogbolomabiri communities were selected from Okrika and Nembe Local Government Areas in Rivers and Bayelsa states respectively as study areas (Figure 1).

Sampling Techniques: Rivers and Bayelsa states were selected out of the nine states of the Niger Delta based on the relative abundance of these species therein. From a list of local government areas that have these species in abundance in Rivers and Bayelsa States one from each state was randomly selected. Finally two communities were randomly selected from each local government area. In all, four communities were selected. A set of questionnaires were randomly administered to $4 \%$ of the total number of households in the selected communities. The number of households were determined by "Listing of households" as is consistent with Omonona (2000) and Ijeomah et al. (2007). Then the questionnaires were administered systematically to males and females in such a way as to have equal number

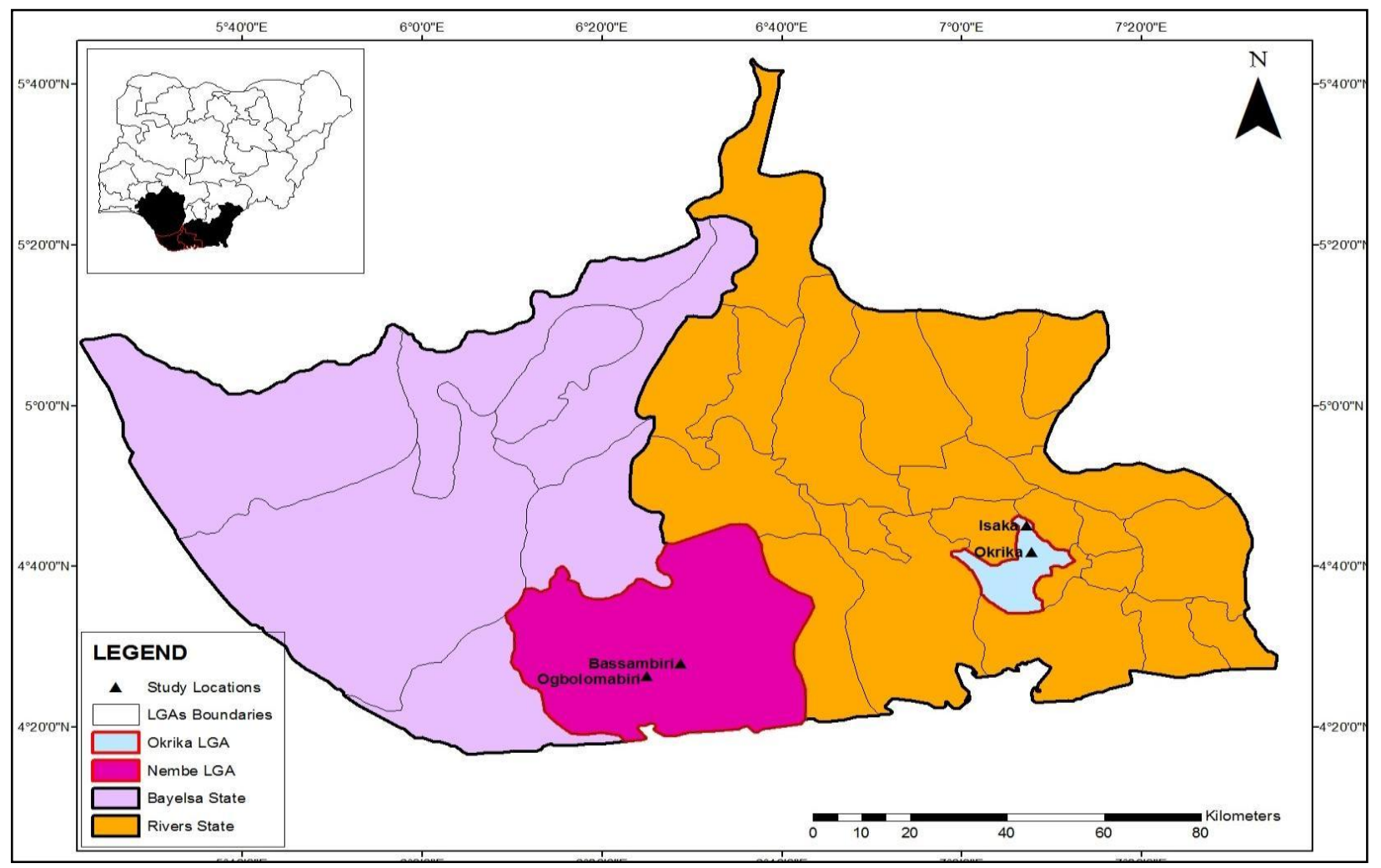

Figure 1: Map of Bayelsa/ Rivers states showing the study areas 
of male and female respondents as shown in Table 1.

Method of Data Collection and analysis: Data for the research project were collected using a set of structured questionnaires, in depth interview and field observation. A set of questionnaires were administered to $4 \%$ of the total households in each selected community in such a way as to have equal number of males and females. In all a set of 301 questionnaires to households were administered (Table1).

In-depth interviews were conducted with indigenes of the four communities who have lived there for a minimum period of ten years and are therefore quite knowledgeable about harvesting, processing and utilization of the nonvertebrate wildlife resources in the community.

Data collected were subjected to descriptive statistics (frequencies and percentages), and presented in tables, so as to determine the importance of the species in the Niger Delta. Also Chi square was used to test for association between the respondents ${ }^{\text {ee }}$ socio demographic characteristics, and their knowledge of the wildlife species with utilization.

\section{RESULTS}

Most respondents had good knowledge of the species (including their local names), and utilize them in various ways (Tables 2, 3 and 4).

The Edible maggot is the least utilised. Chisquare tests showed no association $(p>0.05)$ between occupation and utilisation $\left(\mathbf{X}^{\mathbf{2}}=\right.$ $\left.3.553^{\mathrm{a}}\right)$, also no association ( $\left.\mathrm{p}>0.05\right)$ between age and utilization $\left(\mathbf{X}^{\mathbf{2}}=3.553^{\mathbf{a}}\right)$ (Table 2). However, Chi square results revealed significant association $(\mathrm{p}<0.05)$ between knowledge of the species and utilization $\left(\mathbf{X}^{2}=158.457^{\mathbf{a}}\right)$, and significant association $(\mathrm{p}<0.05)$ between size of household and utilization of these species $\left(\mathbf{X}^{\mathbf{2}}=166.699^{\mathbf{a}}\right)($ Table 3).

\section{DISCUSSION}

Crab, Oyster, Periwinkle and Edible maggots are utilized by most respondents in the study area (Table 2). Irrespective of age, levels of education, occupation and gender respondents utilise these non vertebrate wildlife species (Tables 2, 3 and 4). Female respondents, however, are more selective in consuming these species (especially Crab) than males. Most females dislike consumption of $\mathrm{Crab}$ as they claim that it irritates their throats. Chi square test of association $(p<0.05)$ revealed that size of household affects the consumption of some of the species (Table 2). The educated respondents are more knowledgeable of the dietary importance of the species, thus tend to eat them along with the non educated rural dwellers. The non - formally educated ones eat them as their cultural food and the fact that they are readily available. In a large family, members tend to be less selective as an adaptive strategy to survive economic hardship. Even if most members of a household do not eat the edible maggot, in large households, there is a high tendency of consumption of the species by a member.

Utilisation of these species differs on community basis and is associated $(\mathrm{p}<0.05)$ with the knowledge of these species in a locality. This agrees with the report of Udofia et al 2009 that utilisation of non timber forest products is

Table 1: Proportional allocation of respondents in selected communities

\begin{tabular}{llll}
\hline Community & $\begin{array}{l}\text { No. } \\
\text { house- } \\
\text { holds }\end{array}$ & $\begin{array}{l}\text { No. Sampled } \\
(\mathbf{4 \%} \text { of the } \\
\text { population) }\end{array}$ & $\begin{array}{l}\text { No. of fe- } \\
\text { males } \\
\text { (males) }\end{array}$ \\
\hline Ogbolomabiri & 2049 & 81 & $41(41)$ \\
Bassambiri & 1803 & 72 & $36(36)$ \\
Okrika & 1993 & 78 & $39(39)$ \\
Isaka & 1743 & 70 & $35(35)$ \\
Total & 7585 & 301 &
\end{tabular}


based on the availability and knowledge of the products in different localities. Most respondents from Okrika and Isaka do not eat the Raphia palm weevil larvae because their parents never ate them, thus consumption of the species was not indigenously introduced to them. A few inhabitants of Okrika that consume the edible maggot are indigenes of Bayelsa and Akwa-Ibom States who are resident in Okrika. This is an indication that people from other areas of the Niger Delta, outside the study area eat these species. Utilization of the Callinectes spp., Ostreal Crassostrea spp. and the Littorina spp. by most of the respondents can be related $(\mathrm{p}<0.05)$ with respondents ${ }^{\text {ee }}$ high level of knowledge of the species in the study area (Table 2). Rhynchophorus species is comparatively the least known and therefore the least utilized in the study area. In Okrika and Isaka the local names are not even known, but in Ogbolomabiri and Bassambiri the maggot is locally referred to as "Noun" and valued as a source of food.

The four species are utilized as food in the entire study area. Most respondents utilise Periwinkle (78.55\%), Oyster $(72.28 \%)$ and Crab $(71.95 \%)$ as food. Among the four studied non vertebrate species, the edible maggot is the least utilised as food in the study area. This can be attributed to the fact that the edible maggot is the least known by respondents among the four studied species (Table 3). In Nembe the edible maggot is mainly fried, and sometimes eaten with processed cassava chaff locally called „Ifiniyai' or 'Kpo-kpo garri'. However, it is less frequently eaten with "Ifiniyai", as snacks on sticks (Table 4). The edible maggot is also utilized as food and sold to generate income. The land Crab locally referred to as "Olü in the four studied communities is consumed boiled or roasted. The water Crab (called Ipa- $a$ and Ikorli in Okrika and Nembe respectively) is also prepared in the same manner. It could also be used in the preparation of Crab soup „Ikorli fulo' in Nembe after removing the shells. The fleshy
Table 2: Chi square tests of association between utilization of the species and Social characteristics of respondents

\begin{tabular}{|c|c|c|c|c|c|}
\hline \multirow[t]{2}{*}{$\begin{array}{l}\text { Characteristics of } \\
\text { respondents }\end{array}$} & \multicolumn{4}{|c|}{$\begin{array}{l}\text { Percent- } \\
\text { ages }\end{array}$} & \multirow[b]{2}{*}{$\begin{array}{l}\text { TO } \\
\%\end{array}$} \\
\hline & $\mathrm{I} \%$ & $\mathrm{II} \%$ & $\begin{array}{l}\text { III } \\
\%\end{array}$ & IV \% & \\
\hline \multicolumn{6}{|l|}{ Gender } \\
\hline Male & 26.7 & 24.0 & 26.6 & 22.6 & 49 \\
\hline Female & 27.1 & 23.8 & 25.8 & 23.1 & 49 \\
\hline \multicolumn{6}{|l|}{ Age of respondent } \\
\hline $18-30$ & 26.5 & 27.2 & 30.3 & 15.9 & 43 \\
\hline $31-45$ & 26.5 & 23.4 & 29.6 & 20.3 & 21 \\
\hline $46-60$ & 30.8 & 19.1 & 19.1 & 30.8 & 22 \\
\hline 61 and above & 21.6 & 21.6 & 18.9 & 37.8 & 12 \\
\hline \multicolumn{6}{|l|}{ Level of education } \\
\hline $\mathrm{BSc}$ & 4.7 & 42.8 & 33.3 & 19.0 & 13 \\
\hline B.Ed & 33.3 & 38.8 & 0.0 & 27.7 & 5 \\
\hline OND/HND & 30.3 & 9.0 & 48.4 & 12.1 & 21 \\
\hline NCE & 52.2 & 13.6 & 11.3 & 22.7 & 14 \\
\hline SECONDARY & 28.1 & 26.5 & 10.9 & 34.3 & 21 \\
\hline PRIMARY & 17.3 & 23.9 & 39.1 & 19.5 & 15 \\
\hline NON-FORMAL & 19.0 & 33.3 & 14.2 & 33.3 & 6 \\
\hline \multicolumn{6}{|l|}{ Occupation } \\
\hline Fishing & 19.1 & 28.7 & 19.1 & 32.8 & 24 \\
\hline Farming & 42.8 & 28.5 & 0.0 & 28.5 & 2 \\
\hline Trading & 23.3 & 20.3 & 34.9 & 21.3 & 33 \\
\hline civil service & 47.1 & 16.9 & 20.7 & 15.0 & 17 \\
\hline Unemployed & 24.6 & 27.6 & 27.6 & 20.0 & 21 \\
\hline \multicolumn{6}{|l|}{ Size of households } \\
\hline below 5 & 24.0 & 17.3 & 28.8 & 29.8 & 34 \\
\hline 5 to 8 & 33.6 & 23.6 & 23.6 & 19.0 & 36 \\
\hline 8 to 12 & 26.4 & 28.3 & 22.6 & 22.6 & 17 \\
\hline above 12 & 14.7 & 38.2 & 29.4 & 17.6 & 11 \\
\hline
\end{tabular}

I Ogbolomabiri community, Bayelsa state

II Bassambiri community, Bayelsa State

III Okrika community, Rivers State

IV Isaka community, Rivers State

Majority of the respondents utilized Crab, Oyster,

Periwinkle, but only a few respondents claim to utilise the Edible maggot. 
part of Periwinkle and Oyster are removed from their shells and used in preparing all sorts of foods. Bean(s) is cooked with either/ or both Oyster and Periwinkle in Nembe, as is done in Ogbia, Bayelsa State. For preparation of different kind of soup ( Egusi, Okra, etc.), the Littorina spp. is removed from the shell using a sharp pin. Wikipedia (2011) gave a similar report that the species are extracted in Britain using pin. After extraction, it is used in preparing soup „Fulo" rich in other sea foods like clam and limpets in most Ijaw speaking communities of the region, as is observed in Kalabari. In Nembe, Periwinkle is solely used in large quantity to prepare Periwinkle soup „Isemi fulo". Utilisation of Periwinkle in this manner is obviously a way to reduce cost of living as only soup thickeners are procured.

Periwinkle is also used in ceremonies like burials in the study area, particularly in Nembe, at a chief"es burial, a feast „Fiyai de $e^{\text {ee }}$ is prepared; where several cultural dishes are displayed - the periwinkle is roasted (,Foi isemi') and served in the shells along with processed cassava chaff fried in palm oil „Gbangiri- ifiniyai'. Each chief present in the ceremony is culturally expected to eat from all the displayed foods including the Foi isemi and Gbangiri-ifiniyai. Another type of dish indigenous to the Ijaw people of Bayelsa State that is prepared with periwinkle is -,Kekefiyaie (meaning chopped food). The basal parts of the species are chopped off with knife, then washed and used together with other ingredients (depending on the userse choice) in cooking chopped plantain. This agrees with the findings of Maurice (2004) that the chopped periwinkle is used in making „Ekpang nkukwo" in Akwa Ibom and Cross Rivers States, specifically by the Efik people. However, Ekpang nkukwo unlike the Kekefiyai is prepared with grated water yam and/or cocoyam with addition of other local ingredients.
Traditional medicines over decades have been used in preventing and curing ailments. Apart from plants and some other animalse parts, non vertebrate species were also used. These species have been used together with other wildlife resources for this purpose. Crabs are used with palm kernel oil for curing severe chesty cough in the Niger Delta region. Crab specifically the Blue-red land Crab locally referred to as "Souguru" by the Okrikas, is roasted and ground, then mixed with Palm kernel oil and administered to the patients. The utilization of this species is similar amongst the Nembes. Inhabitants of the study area believe that Crab is a source of blood to human body, for this reason it is used in preparing pepper soup for sick persons in Okrika.

To lure and trap wildlife species, other wildlife resources are used, the live periwinkle upon extraction from the shell for instance is used in fishing: using hook and line fishing gear- a hook is pierced through it, there after it is used by local subsistence fishermen to attract and catch different species of fish. The Crab is also used as bait in fishing. It is specifically used in harvesting mud skipper fish (Periophthalmus barbarus) locally called "Ichila" in Okrika (Table 2). This is done at a time when the river has ebbed. The crab is ground and put inside a cut rubber bottle typically an empty Jik bleach bottle (bottle whose basal part has been cut off). The supposed mouth of the bottle is inserted into the ground in such a way that it is slanted, so that the cut part having the bait touches the marshy mangrove floor. When the fish source for the bait, upon eating it they are trapped as they slide in and remain therein. After several fish have been trapped within, they are emptied into a container, and the cycle begins again until the required harvest level is reached. This is the only method of fishing the mud skipper known to respondents in the study area (except in Nembe), and the method is employed on both subsistence and commercial basis. Crab is not used for this purpose in Nembe because indigenes of the community 
do not eat mudskipper (Itila) due to their belief that they feed on human feaces.

Empty Oyster shells are utilized as native chalk in both Nembe and Okrika communities. It is locally called „Itor $u^{\prime \prime}$ in Nembe and "Toru" in Okrika, and is prepared mainly from the big Oyster (Crassostrea gigas) shells. The empty shells are roasted, ground and sieved, then the fine powder is used to make a paste before applying on the body. Also, it is used for body adornment on chiefs before/during installation, and by witch doctors before carrying out their rituals (Table 2). The use of ashes for scouring powder is widely known by people in the region, as is the case of periwinkle and oyster shells. The shells are roasted and ground into fine powder, and then used with detergent for scrubbing cooking utensils. Interactions with respondents confirmed that this use is similar for both the Nembe and Okrika and other areas of the Niger-delta. The use of shells of some non vertebrate species (Oyster, periwinkle and others like the limpet) in feeds is also known by the people who claim that it helps in the growth of poultry birds, when incorporated into their feeds. This agrees with the work of Idoniboye et al. (1993) that these shells are used as calcium supplement for poultry birds. Kalio et al (2010) obtained similar result that they are used in preparing fish feed.

After extracting the fleshy part of periwinkle, some of the empty shells are returned into the water by some respondents in the region; when no immediate use of the shells is needed. This is evident as empty sea whitewashed shells are seen on the shore lines, though this could have environmental consequences as decaying remains of flesh could cause water pollution and increase water turbidity while giving off offensive odours. However, these empty shells serve as habitats for species like the Hermit crab (Pagurus longicarpus). That is the reason it is often mistaken for the Periwinkle and picked during harvesting in the study areas. This is consis- tent with the findings of Wilber and Herrnkind (1982), Pechenik et al. (2001) and Ohimain et al. (2001). The utilization of these species $^{\text {ee }}$ shells (Periwinkle and Oyster) cannot be overemphasized as they are even seen around dwelling places, on the roads and pavements in the study area, where they are used (poured on the ground) with the aim of elevating frontages, solidifying marshy grounds, and to combat erosion- for houses by river banks. The shells are also utilized in place of gravel for construction work in both study areas" sub urban and urban vicinities of the Niger Delta, including Port Harcourt City.

These shells are mixed with sand and cement then used for flooring, decking and pillar making when building houses. Similar results were obtained in Benin City that is also part of the Niger-delta region (Osarenmwhinda and Aware 2009). Also, they have been used over decades in making graves in Nembe and Okrika. Similar use has been observed in Ogbia Local Government Area of Bayelsa; Andoni and Bonny areas of Rivers States and other areas of the Niger Delta. They are utilized as coarse aggregates in order to reduce costs of gravel. They are also used in decorating houses- in the form of art work (because of their lustre virtue) on walls and floors, for the purpose of beautification. In Akwa Ibom State of Niger Delta, shells of Periwinkle and Oyster are sacked and used in checking erosion. The various uses the shells of Oyster and Periwinkle can be put to in the study area conforms to with the report of Ademoroti (1996) that they are reclaimable, recyclable and reusable materials.

\section{CONCLUSION}

Crab, Callinectes spp; Oyster, Ostrea edulis; Periwinkle, Littorina irrorata; and the Raphia palm weevil Larvae, Rhynchophorus phoenicis play vital roles in the culture and nutrition of people of Niger Delta. The respondents attempt to put the resources in their environment to various uses in order to survive. If 
these resources which the lives of many depend upon become unavailable, the decline may possibly lead to starvation, reduced income or increased the vulnerability of the rural poor collectors to diseases and poverty.

\section{REFERENCES}

Food and Agriculture Organization (FAO) 1997 Wildlife and Food Security in Africa (ed) Yaa N B FAO, Conservation Guide No.32. Rome.

Idoniboye-Obu TIE, Ayinla OA and Alfred-Ockiya J.F. 1993 Utilizing Crab Meal as Partial Substitute for Dried Brewer"s Yeast in a Practical Diet for Tilapia guineensis. Journal of Aquatic Sciences 8:1121.

Kalio G A, Etela I, Fredrick I and Ugwo E O 2010 Pawpaw Leaves Supplemented with three Calcium Sources and their Effects on the African Giant Land Snail in Humid Nigeria. Rivers state. The Journal of Agriculture and Social Research (JASR) 10 (1): 2010-2043.

http://www.ajol.info/index.php/jasr/article/ viewFile/67523/55636. Accessed 20:09:2011.

Maurice A 2004 Nigeria: Gold mine waiting to be tapped (1) The Sun News on Line.

http: //64.182.81.172/ webpages/features/travels/ 2004/ mar/18/travels-mar18-01.htm. Accessed 08:11:2011.

Ogogo A U 2008 Wildlife Management in Nigeria,(2nd edition). Median Communications Calabar, Cross River State.280pp.

Ohimain IE, Bassey S and Bawo DS 2009 Uses of Sea Shells for Civil Construction Works in Coastal Bayelsa State, Nigeria: A Waste Management Perspective. Research Journal of Biological Sciences.4 (9): 1025-1031. Error! Hyperlink reference not valid. Error! Hyperlink reference not valid. Error! Hyperlink reference not valid.Accessed 23:09:2011.

Omonona BT 2000 Poverty and it"s correlates among rural farming households in Kogi, Nigeria. Phd Thesis. Department of Agricultural Economics, University of Ibadan, Nigeria. 209pp.
Osarenmwhinda JO and Awaro AO 2009 The Potential Use of Periwinkle Shells as Coarse Aggregate for Concrete. Department of Production Engineering, University of Benin, Benin City,Nigeria. Advanced Materials Research.62(64):393.www.scientific.net. Accessed 23:09:2011.

Osemoebo G J 1991 Effect of Common Property Resource Utilization on Wildlife Conservation in Nigeria. Geo. Journal 23:241-148.

Pechenik JA; Hsieh J; Owara_S; Wong P; Marshall D and Wei L 2001 Factors of Selectivity for Avoidance of Drilled Shells by the Hermit Crab (Pagurus Longicarpus). Journal of Marine Biology and Ecology. 361 (1): 75-89.

Poopola FS, Abu JE, Isese MO, Ohenzuwa U B and Isebemhe E 2010 Forestry a Veritable Tool for Food Security. Global Economic Crisis and Sustainable Renewable Natural Resources Management. Paper presented at the $33^{\text {rd }}$ conference of Forestry Association of Nigeria (eds) Poopola L, Idumah FO, Adekunle, VAJ, Azeez IO Held in Benin-city, Edo state Nigeria between $25^{\text {th }}-29^{\text {th }}$ October., Pp.456- 467.

Udofia SI, Offiong MO, Ijeomah HM and Etefia JO 2009 Non Timber Forest Products in the Household Economy of Ini Local Government of AkwaIbom State Nigeria. Nigeria Journal of Agriculture, Food and Environment. 5(1):52-58.

Wikipedia, 2011 Wikipedia the free encyclopedia .Crab. http://en.wikipedia.org/wiki/Crab. Accessed 17:09:2011.

World Health Organization WHO 1985 Energy and Protein Requirements. Report of a joint WHO/ UN Expert Consultation. Technical Report series No. 32. Rome. 